
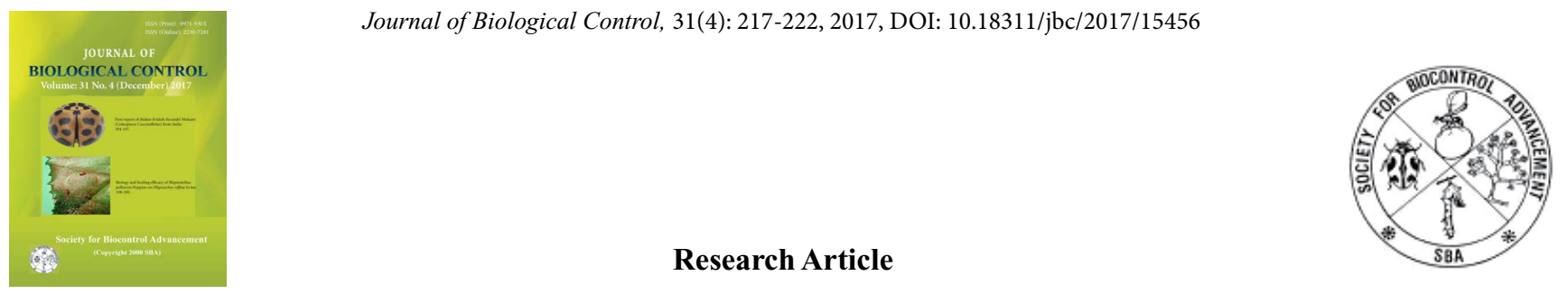

\title{
Evaluation of fungal and bacterial antagonists for managing phytopathogen Fusarium moniliforme var. subglutinans Sheldon, causing Pokkah Boeng disease of sugarcane
}

\author{
ANSHUL ARYA, ROOPALI SHARMA*, GEETA SHARMA, BHUPESH CHANDRA KABDWAL, ARCHANA \\ NEGI and BHAVYA MISHRA \\ Department of Plant Pathology, College of Agriculture, G. B. Pant University of Agriculture and Technology, Pantnagar - 263145, \\ Uttarakhand, India \\ ${ }^{*}$ Corresponding author E-mail: roopalibiocontrol@gbpuat.ac.in
}

\begin{abstract}
In the present investigation potential fungal and bacterial antagonists were tested under laboratory and field conditions against the phytopathogen Fusarium moniliforme var. subglutinans Sheldon, causing Pokkah Boeng disease of sugarcane. Different strains of fungal anatagonists viz; Trichoderma spp. (strains TCMS36, TCMS43, Th3, TCMS9, Th14) and bacterial antagonists viz; Pseudomonas fluorescens (strains Psf173 and Psf02) and Bacillus sp. were tested against the pathogen under in vitro conditions by employing dual culture technique and volatile assay. The results from dual culture revealed that TCMS36 showed the maximum radial growth inhibition i.e., 73.33 per cent followed by Th14 (69.01\%), Psf02 (68.33\%), Th3(66.04\%),TCMS43 (64.7\%), Bacillus sp. (63.95\%) and TCMS9(63.74\%). Volatile assay depicted that the maximum radial growth inhibition was found in TCMS36(70.01\%) followed by TCMS9 (60.10\%), Th3 (57.25\%), Th14 (55.36\%), Psf02 (50.83\%) and Bacillus sp. (51.79\%), while minimum growth inhibition was observed in Psf173 (40.49\%). Further studies were conducted in field, where, Th 14, Psf02 and the consortium of both (Th 14+Psf 02) were tested through sett treatment. The minimum disease incidence was observed in the treatment where setts were treated with P. fluorescens (Psf02) followed by consortium (Th $14+$ Psf 02 ) and Th 14 i.e. $0.92 \%, 1.51 \%$ and $5.53 \%$, respectively. The findings from research conclude that the fungal and bacterial antagonist strains can exert an inhibitory effect on the radial growth of Fusarium sp. as well as reduce the disease incidence in field. Application of these antagonists in field could be a better management tool without having to depend on hazardous chemicals.
\end{abstract}

KEY WORDS: Bacillus sp., Fusarium sp., Pokkah boeng, Pseudomonas spp., Trichoderma spp

(Article chronicle: Received: 22-02-2017; Revised: 15-09-2017; Accepted: 30-11-2017)

\section{INTRODUCTION}

Pokkah boeng disease of sugarcane is a potentially destructive disease affecting the quality and yield of the crop. Pokkah boeng, a Javanese term denoting a malformed or distorted top, was originally described by Wakker and Went (1896) in Java. The pathogen Fusarium moniliforme var. subglutinans Sheldon, is the causal organism for the disease. Disease incidence was observed from trace to moderate level on most of the commercial varieties grown in India but the severity was high in Uttar Pradesh and Maharashtra (Duttamajumdar, 2004). The yield losses due to Pokkah boeng disease depend on the varieties of crop grown and vary from 5 to 90 percent in some cultivars. The disease normally appears during periods of hot humid conditions when the cane is growing rapidly, from late spring to end of the summer. Infection takes place by air borne conidia, infected setts, splashed rains and soil (Vishwakarma et al., 2013). The incisive management of the disease can only prevent the damage caused by the pathogen to the commercial sugarcane varieties. As the infected sets are the carrier of the pathogen in the field, use of the sett treatment can be a suitable management practice. Various fungal and bacterial bioagents have the potential to control several soil borne diseases without taking the environmental and health issues at a risk. In the present investigation Trichoderma spp., Bacillus sp. and Pseudomonas spp. have been tested for their antagonistic potential against the phytopathogen and found effective for inhibiting the radial growth of pathogen under in vitro conditions as reported by the several scientists. Sharfuddin and Mohanka (2012) demonstrated that different isolates of Trichoderma, isolate- 5 and $7 \mathrm{of} \mathrm{Th}$, 
2 and 18 of Tv and isolate 9 of Tk were found efficient for control of Fusarium oxysporum f.sp. lentis; causing wilt of lentil, a disease prevalent in Bihar. Raza et al. (2014) evaluated the antifungal potential of volatile and non-volatile compounds of Trichoderma harzianum against Fusarium oxysporum in vitro and demonstrated that strain T. harzianum strain SQR-T037 produced volatile compounds that can inhibit the growth of $F$. oxysporum $\mathrm{f}$. $\mathrm{sp}$. niveum causal agent of Fusarium wilt of watermelon. Negi et al. (2014) confirmed that seed treatments with bioagents $T$. harzianum, Pseudomonas fluorescens and T. harzianum $+P$. fluorescens in vegetable pea were found to be superior to control Rhizoctonia solani, Fusarium solani and their complex over untreated control in disease severity parameter. Thus, in the present study we focused on the identification of most effective bioagent against Fusarium sp. having maximum antagonistic potential against the pathogen, F. moniliforme var. subglutinans by employing the volatile assay and non volatile assay and use of the bioagents for sett treatment to see the impact on disease incidence under field conditions.

\section{MATERIALS AND METHODS}

\section{Isolation of Pathogen}

Samples or specimens of Pokkah boeng were obtained from the Sugarcane Pathology block of Norman E. Borloug Crop Research Centre, Pantnagar, 2014. Canes exhibiting clear cut symptoms of the disease viz., Chlorosis, Top rotting and Knife cut were collected and brought to the laboratory for isolation of the pathogen (fungus). The diseased parts of leaves and top rotted cane were cut into small pieces from the margin of the lesion along with 50 per cent of the healthy tissue, they were surface sterilized with 2 per cent sodium hypochloride solution for about 1 min and the pieces were transferred into Petri dishes containing sterilized distilled water and washed thoroughly. Washed pieces were dried on sterilized blotter paper. Four surface sterilized pieces were placed onto potato dextrose agar (PDA) in Petri plates under aseptic conditions. Inoculated Petri dishes were then incubated at $25 \pm 2{ }^{\circ} \mathrm{C}$ in BOD incubator for 7 days to get full growth of fungus. At the end of incubation period, the minute fungal growth was cut with the help of inoculation needle and transferred in the slants of PDA medium. Then these inoculated slants were kept in BOD incubator at $25 \pm 2{ }^{\circ} \mathrm{C}$ temperature for further growth.

\section{In Vitro Assessment of Antagonists \\ Dual Culture Assay \\ For fungal antagonist}

Trichoderma harzianum isolates viz; TCMS36,
TCMS9, Th3, TCMS43 and Th14 were tested for their antagonistic effect against Fusarium moniliforme var. subglutinans, by "Dual Culture Technique" as described by Morton and Stroube (1955) under in vitro condition. For the experiment, fifteen $\mathrm{ml}$ of sterilized melted PDA medium was poured aseptically under Laminar Air Flow into sterilized Petri plates. $5 \mathrm{~mm}$ discs of the antagonist and the test fungus were cut from the edge of 7 days old culture by sterilized cork borer, was placed in Petri plates after solidification of the medium. The discs were placed in a straight line at distance of $1 \mathrm{~cm}$ from the edges of Petri plates. Three replications were maintained for each treatment along with control. Then inoculated Petri plates were incubated at $25 \pm 2^{\circ} \mathrm{C}$ and observations were recorded for next seven days, inhibition zone was estimated on the basis of formula given by Vincent (1947), Percent Inhibition (PI) $=\mathrm{C}-\mathrm{T} / \mathrm{C}$ $\mathrm{x} 100$ Where, PI = percent inhibition, $\mathrm{C}=$ Growth of test pathogen in absence of antagonist $(\mathrm{cm}), \mathrm{T}=$ Growth of test pathogen in presence of antagonist $(\mathrm{cm})$.

\section{For bacterial antagonist}

To evaluate the efficiency of bacterial antagonist viz; Pseudomonas fluorescens (Psf173,Psf02) and Bacillus sp. the bacteria was grown in PD broth and a disc of $5 \mathrm{~mm}$, dipped in bacterial suspension placed at one side of Petri plate containing PDA medium and on other side disc of the test pathogen was placed, leaving $1 \mathrm{~cm}$ space from the edges. Then the plates were kept in incubator and observations were recorded by estimating inhibition zone by using Vincent's formula as described earlier.

\section{Volatile Assay}

\section{For fungal antagonist}

Antifungal volatile compounds assay was conducted in dual plates. The PDA (potato infusion $200 \mathrm{~g}$, dextrose $20 \mathrm{~g}$, agar $15 \mathrm{~g}$ in $1 \mathrm{~L}$ of distilled water) medium was used to inoculate fungal antagonists in one plate except control plates and the other plates containing PDA medium was used for F. moniliforme var. subglutinans to test the growth inhibition of the volatile compounds. The pathogen containing plate was placed over antagonist containing plate and both plates were sealed with parafilm and incubated at $27 \pm 2^{\circ} \mathrm{C}$ for three days and then the diameters of the fungal growth on the plates were measured up to 3 days. The measurement and the percentage of mycelial growth inhibition were calculated as described earlier.

\section{For bacterial antagonists}

An overnight bacterial culture in broth was streaked onto a Nutrient Agar medium plate. The lid was replaced by a base plate of PDA containing a $0.5 \mathrm{~mm}$ diameter agar 
plug from an actively growing fungal mycelium of $F$. moniliforme var. subglutinans. The two base plates were sealed together with Parafilm. Control sets were prepared without bacteria in the bottom plate. The diameters of the fungal colonies, on three replicates, were measured after 4 days incubation at $27 \pm 2^{\circ} \mathrm{C}$ temperature. The measurement and the percentage of mycelial growth inhibition we calculated as described earlier.

\section{Evaluation of bioagents in field Sowing of sugarcane crop in field}

Sowing was done on $04^{\text {th }}$ April, 2014 at optimum soil moisture level for proper germination following the routine method of planting of sugarcane. Setts were planted in $2 \mathrm{~m}$ rows (row-row distance was $0.75 \mathrm{~m}$ ) by conventional method of planting, maintaining 3 replications for each treatment in Randomized Block Design. Each plot was of 2 rows and size of each plot was $2 \times 0.75$ sq.mt. 3 budded setts of the variety Co1148 were treated by dipping the setts for one hour in the solution of bioagents prepared in water before sowing as per following treatments. Carbendazim was used as positive check for the sett treatment as this chemical is recommended for the foliar spray in field to control the disease and is also used for the seed treatment to control many seed borne diseases.

\section{Bioagents treatment}

T1 : Trichoderma harzianum Th14@15g bioagent in 1litre water.

T2 : Pseudomonas fluorescens Psf02@15g bioagent in 1 litre water.

T3 : T. harzianum Th14 + P. fluorescens Psf02@7.5g each in 1 litre water.

\section{Positive chemical check}

T4 : Carbendazim 50WP (Bavistin)@ $0.1 \%$.

\section{Incidence of disease in natural condition}

The presence or absence of disease in field was identified on the basis of symptoms i.e., chlorosis, top rotting and knife cut, therefore, disease incidence was calculated as number of infected plants showing above mentioned any single symptom out of total numbers of sugarcane plants observed. The observations were recorded 150 days after sowing of the crop at fifteen days interval when canes were at their rapid growth stage till the fortnight of November when new infection of disease did not appear in field. Disease incidence is the percentage of diseased plants in the sample or population of plants. Estimation of the plant Disease incidence was done by using the following formula:

$$
\text { Disease Incidence }=\frac{\text { Average No. of infected plants }}{\text { Total no. of plants assessed }} \times 100
$$

\section{RESULTS AND DISCUSSION}

Dual culture technique is used for assessing the antagonistic effect of different bioagents against the pathogen. While studying the interaction between the pathogen Fusarium moniliforme var. subglutinans and bioagents, the results of dual culture technique revealed (Fig. 1) that among the different bioagents Trichoderma harzianum strain TCMS 36 showed the maximum per cent inhibition in radial growth of pathogen which was 73.33 per cent followed by the strain Th14 (69.01\%), Pseudomonas fluorescensstrain Psf02 (68.33\%), Th3 (66.04\%), TCMS36 (64.70\%), Bacillus sp. (63.95\%), TCMS9 (63.74\%) and Psf173 was found least effective showing per cent growth inhibition of 51.74 per cent. In case of bacteria P. fluorescens Psf02 was found to be more effective than the Bacillus sp. The results on volatile assay (Fig. 1) revealed similar trend and maximum per cent growth inhibition i.e., 70.01 per cent was recorded by $T$. harzianum strain TCMS 36 followed by TCMS9 (60.10\%), Th3 (57.25), Th14 (55.36\%), TCMS43 (53.63\%), Psf02 (51.83\%), Bacillus sp. (51.79\%) and Psf173 was found least effective showing minimum growth inhibition of 40.49 per cent as compared to others. It was found that all the biological agents have good potential to reduce the growth of the pathogen either by direct parasitism or through utilizing their volatile compounds. It can be concluded that $T$. harzianum strain TCMS36 and P. fluorescens strain Psf02 were significantly effective and both of them can be utilized to control the pathogen. The results observed from the volatile assay were following the same trend of inhibiting the growth of pathogen as in case of dual culture. Observation in Table 1 shows that the consortium of the fungal and bacterial antagonist is effective in getting the maximum yield i.e. $48.35 \mathrm{~kg} / \mathrm{plot}$ with increase in other attributes of the crop yield i.e. increase in cane length and weight, significantly higher yields were obtained in all the other treated T. harzianum Th14 $(38.13 \mathrm{~kg} /$ plot), P. fluorescens Psf02 (43.22 kg/plot), fungicide ( 32.27 $\mathrm{kg} / \mathrm{plot})$ when compared to control $(28.80 \mathrm{~kg} / \mathrm{plot})$. The bacterial antagonist individually showed the least disease incidence i.e., $0.92 \%$ as compared to other treatment where the disease index observed was $1.51,5.53,9.25$ and $1.70 \%$ for consortium, T. harzianum Th14, control and positive control, respectively. Control plot showed the maximum disease incidence. A significant increase in the brix value, sucrose content, juice purity and CCS percent was observed in the canes where sett treatment was given with the bioagents when compared with the control and positive check. Maximum brix per cent was observed in canes where sett treatment was done with Trichoderma harzianum Th14 i.e., $20.06 \%$ and least was observed in case of control i.e., $19.66 \%$. These bioagents are not only effective in disease control, but also play important role in increasing the yield 
of the sugarcane crop.

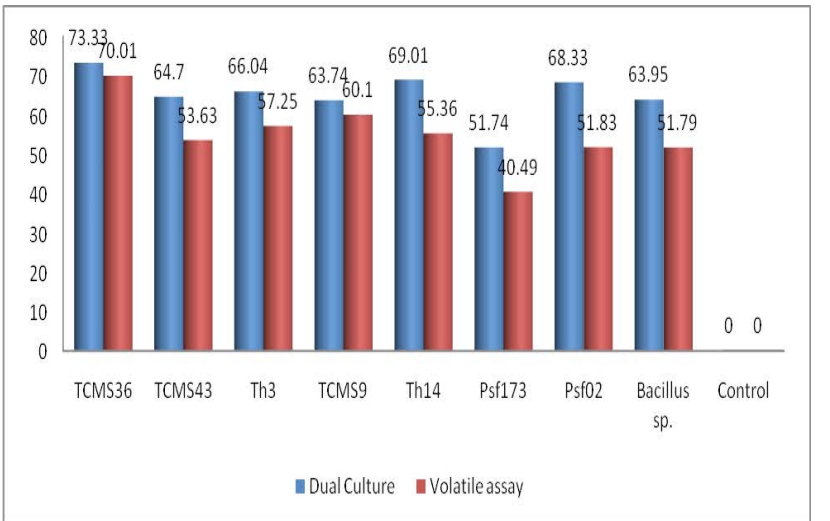

Fig. 1. Per cent mycelial growth inhibition of Fusarium moniliforme var. subglutinans Sheldon, by antagonists Trichoderma harzianum, Pseudomonas fluorescens and Bacillus sp. by employing dual culture and volatile assay techniques.

Sugarcane is a very important crop for the country like India and disease management of such crop is very important to reduce the yield losses. Pokkah boeng disease can become a devastating disease in future. Management of this disease has become a challenge for the scientists. In recent years, use of bioagents has been gaining more attention. Among the bioagents Trichoderma spp. is the most widely studied against plant pathogens because of their ability to reduce the population of soil borne plant pathogens (Papavizas, 1985). Pseudomonas fluorescens has also proved to be a successful bioagent as it can manage the phytopathogenic microbes. The potential of Bacillus spp. as biological control agents has been previously reported by several scientists (Korsten et al., 2000). Results of dual culture assay and volatile metabolites of Trichoderma spp., P. fluorescens and Bacillus sp. indicate that the tested bioagents were capable of inhibiting the growth of Fusarium moniliforme var. subglutinans. Dal Bello et al. (1997) studied the volatile compounds produced by Trichoderma sp. against various phytopathogenic fungi and suggested the inhibitory volatiles of Trichoderma sp. as one of the possible mechanism of biological control. Previous studies have demonstrated that before the mycelial interaction, Trichoderma sp. produces low quantities of extracellular exochitinases (Kullnig et al., 2000; Brunner et al., 2003). The diffusion of these enzymes dissolves cell fragments of host cells. These cell fragments in turn induce the production of further enzymes that trigger a cascade of physiological changes, stimulating rapid and directed growth of Trichoderma spp. (Zeininger et al., 1999). The volatile test showed results were in accordance with Sivasithamparam and Ghisalberti (2002) which indicated that different species of the same family and different strains of the same species often can produce significantly different compounds. Sett treatment with bioagents makes the plant somewhat resistant to the disease through the induction of defense mechanism of the plant and by increasing the vigor of the plant that leads to the reduced disease incidence and increased yield. The findings of sett treatment are in accordance with the earlier work done by Khan et al. (2004), Akrami et al. (2012), Mohamedy and Alla (2013), Sundaramoorthy and Balabaskar (2013) and Negi et al. (2014) where they all reported that use of biocontrol agents not only decreases

Table 1. Effect of bioagents on disease status and yield of sugarcane

\begin{tabular}{|c|c|c|c|c|c|c|c|c|c|c|}
\hline Treatments & $\begin{array}{l}\text { Disease } \\
\text { incidence } \\
(\%)\end{array}$ & $\begin{array}{l}\text { Av. No. } \\
\text { of clumps } \\
\text { Per plot }\end{array}$ & $\begin{array}{l}\text { Av. No. of } \\
\text { millable } \\
\text { canes Per } \\
\text { plot }\end{array}$ & $\begin{array}{l}\text { Av. } \\
\text { Cane } \\
\text { ht }(\mathrm{m})\end{array}$ & $\begin{array}{l}\text { Av. } \\
\text { Cane wt } \\
(\mathrm{kg})\end{array}$ & Brix \% & $\begin{array}{l}\mathrm{Su}- \\
\operatorname{crose} \%\end{array}$ & $\begin{array}{l}\text { Juice } \\
\text { Purity } \\
\%\end{array}$ & $\operatorname{CCS} \%$ & $\begin{array}{l}\text { Cane } \\
\text { Yield } \\
\text { (kg/ } \\
\text { plot) }\end{array}$ \\
\hline $\begin{array}{l}\text { Trichoderma harzi- } \\
\text { anum Th } 14\end{array}$ & 5.53 & 14 & 44.33 & 3.08 & 0.86 & 20.06 & 18.91 & 93.80 & 13.43 & 38.13 \\
\hline $\begin{array}{l}\text { Pseudomonas fluores- } \\
\text { cens Psf02 }\end{array}$ & 0.92 & 16.67 & 49.12 & 3.03 & 0.88 & 19.76 & 18.71 & 94.02 & 13.31 & 43.22 \\
\hline $\begin{array}{l}\text { Trichoderma harzi- } \\
\text { anum Th } 14+\text { Pseu- } \\
\text { domonas fluorescens } \\
\text { Psf02 }\end{array}$ & 1.51 & 18 & 54.33 & 3.11 & 0.89 & 19.86 & 18.04 & 90.97 & 12.64 & 48.35 \\
\hline Control & 9.25 & 10.33 & 28.00 & 2.13 & 0.6 & 19.66 & 17.01 & 86.03 & 11.61 & 28.80 \\
\hline Carbendazim & 1.70 & 12.66 & 37.53 & 2.85 & 0.86 & 19.70 & 16.41 & 78.93 & 10.19 & 32.27 \\
\hline $\mathrm{CD}$ at $5 \%$ & 00.93 & 2.63 & 4.96 & 0.31 & 0.10 & 0.49 & 1.29 & 1.45 & 1.04 & 1.97 \\
\hline $\mathrm{CV}$ & 13.08 & 6.05 & 5.69 & 5.51 & 18.82 & 1.25 & 3.52 & 0.79 & 4.12 & 2.71 \\
\hline
\end{tabular}


the disease severity but also increases plant vigor and ultimately increasing the total yield. Although they have worked on other host crops like bean, tomato, vegetable pea etc. means other than sugarcane, but their work has already proved that fungal as well as bacterial bioagents like Trichoderma harzianum, Bacillus subtilis and Pseudomonas fluorescens have the capacity to suppress soil and seed borne plant pathogens. These bioagents have also been exploited for improving the soil health and thus improving the plant biomass and ultimately affecting the crop yield. Because Pokkah boeng disease of sugarcane is recently reported from the area and not much work has been done to manage the disease so, the data obtained from this experiment could prove a new way for integrated disease management practice not only in reducing the disease incidence but also in improving the crop yield. For tarai area Pokkah boeng is new emerging disease and through the studies conducted, biocontrol agents can be explored for the management of this disease. Therefore, the study establishes the potential use of $T$. harzianum, $P$. fluorescens and Bacillus sp. for controlling Pokkah boeng caused by F. moniliforme var. subglutinans. Though, further studies are necessary in the characterization and usability of volatile metabolites, in which biotechnology may offer a promising solution.

\section{REFERENCES}

Akrami M, Khiavi HK, Shikhlinski $\mathrm{H}$ and Khoshvaghtei H. 2012. Bio controlling two pathogens of chickpea Fusarium solani and Fusarium oxysporum by different combinations of Trichoderma harzianum, Trichoderma asperellum and Trichoderma virens under field conditions. Int J Agri Sci Res. 1(3): 41-45.

Brunner K, Peterbauer CK, Mach RL, Lorito M, Zeilinger S and Kubicek CP. 2003. The Nacetylglucosaminidase of Trichoderma atroviride is essential for chitinase induction by chitin of and major relevance to bio-control. Curr Gen. 43: 289-295. Crossref. PMid:12748812

Dal Bello GM, Mónaco CI and Cháves AR. 1997. Study of the effect of volatile metabolites of Trichoderma hamatum on the growth of phytopathogenic soil borne fungi. Rev Iberoam Micol. 14(3):131-4. PMid:17655390

Duttamajumdar SK. 2004. Bacterial diseases of sugarcane in india: a bird's eye view. In: Rao GP, Saumtally AS, Rott P, Eds. Sugarcane pathology: bacterial and nematodes diseases, Science Publishers. pp. 15-50.

Khan MR, Khan SM and Mohiddin FA. 2004. Biological control of Fusarium wilt of chickpea through seed treatment with the commercial formulation of Trichoderma harzianum and/or Pseudomonas fluorescens. Phytopathol Mediterr. 43: 20-25.

Korsten L, De Jager ES, Paul I, Obagwu J and El-Ghaouth A. 2000. Alternative control of citrus postharvest diseases. Proc Int Soc Citriculture (in press)

Kullnig C, Mach RL, Lorito M and Kubicek CP. 2000. Enzyme diffusion from Trichoderma atroviride to Rhizoctonia solani is a prerequisite for triggering of Trichodermaech 42 gene expression before mycoparasitic contact. Appl Environ. Microbiol. 66: 2232-2234. Crossref. PMid:10788407 PMCid:PMC101480

Martin JP, Hong HL and Wismer CA. 1961. The corresponding heritability estimate for Pokkah boeng. In Sugar-cane diseases of the world. Vol. 1, Elsevier Publ. Co. New York. $542 \mathrm{p}$.

Mohamedy RSR and Alla MAA. 2013. Bio-priming seed treatment for biological control of soil borne fungi causing root rot of green bean (Phaseolus vulgaris L.). $J$ Agri Tech. 9(3): 589-599.

Negi DS, Sharma PK and Gupta RK. 2014. Management of root-rot complex disease and assessment of plant growth promoting characters in vegetable pea with native and commercial antagonists through seed biopriming. Int $J$ Rec Sci. 5(8): 1416-1421.

Papavizas GC. 1985. Trichoderma and Gliocladium: Biology, ecology, and potential for biocontrol. Ann Rev Phytopathol. 23: 23-54. Crossref.

Raza W, Faheem M, Yousaf S, Rajer FU and Yameen M. 2013. Volatile and non-volatile antifungal compounds produced by Trichoderma harzianum SQR-T037 suppressed the growth of Fusarium oxysporum f. sp. niveum. Sci Lett. 1(1): 21-24.

Sharfuddin C and Mohanka R. 2012. In vitro antagonism of indigenous Trichoderma isolates against phytopathogen causing wilt of lentil. Int J Life Sci Pharma Res. 2(3): 195-202.

Sivasithamparam K and Ghisalberti EL. 1998. Secondary metabolism in Trichoderma and Gliocladium, In: Kubicek CP, Harman GE, and Ondik KL (Eds). Trichoderma and Gliocladium: basic biology, taxonomy and genetics. Taylor and Francis, pp. 139-191.

Sundaramoorthy S and Balabaskar P. 2013. Trichoderma spp. against wilt of tomato caused by Fusarium oxysporum $\mathrm{f}$. sp. lycopersici. J Appl Biol Biotech. 1(03): 36-40. 
Vincent JM. 1947. Distortions of fungal hyphae in the presence of certain inhibitors. Phytopathology 48: 268-270. Crossref.

Vishwakarma SK, Kumar PL, Nigam A, Singh A and Kumar A. 2013. Pokkah Boeng: An emerging disease of sugarcane. J Pl Pathol Microbiol. 4(3): 1-5.

Wakker JH and Went FAF C. 1896. Overzicht van de Ziekten van het suikerriet op Java.
Zeininger S, Galhaup C, Payer K, Woo SL, Mach RL, Fekete C, Lorito M and Kubicek CP. 1999. Chitinase gene expression during mycoparasitic interaction of Trichoderma harzianum with its host. Fungal Genet Biol. 26:131-140. Crossref. PMid:10328983 